\title{
ПРАВОВЫЕ ПРОБЛЕМЫ ТОЛКОВАНИЯ ПОНЯТИЯ «ОСВОБОДИВШЕЕСЯ ЖИЛОЕ ПОМЕЩЕНИЕ»: ТЕОРЕТИЧЕСКИЕ И ПРАКТИЧЕСКИЕ АСПЕКТЫ
}

\section{LEGAL PROBLEMS OF INTERPRETATION OF THE CONCEPT «RELAXED RESIDENTIAL ROOM» THEORETICAL AND PRACTICAL ASPECTS}

\section{A. Gudkov \\ A. Krasilschikov \\ V. Mishchenko}

Summary. The article explores some of the problems of law enforcement in the field of housing legislation. In particular, the difficulties associated with the possibility of acquiring vacated residential premises in communal apartments by their other co-owners are highlighted. The legal collisions of the current housing legislation and its conflicting understanding are disclosed in various constituent entities of the Russian Federation, as well as in various judicial instances. Options are proposed for resolving this problem, both by interpreting conflict of laws rules in accordance with the general meaning and principles of housing legislation, and by introducing appropriate changes to it. The authors believe that their proposed solutions will serve the interests of both private entities and public law entities.

Keywords: housing law, communal apartment, vacant housing, preemptive right to purchase, municipal property, corruption, interpretation.

$\mathbf{y}$ же более 15 лет прошло со времени принятия нового Жилищного кодекса РФ [3], который, в первую очередь, должен был разрешить огромную массу накопившихся проблем, связанных со сменой общественно - экономической формации нашего государства.

Важнейшими вопросами, в решении которых появилась потребность на тот момент, были вопросы, связанные с социальным наймом жилых помещений: разработка и реализация нового правового механизма постановки на учёт нуждающихся и новых критериев распределения государственного и муниципального жилого фонда, проблемы, связанные с переселением граждан из в ветхого и аварийного жилья, ликвидацией коммунальных квартир, как пережитков прошлой эпохи,
Гудков Анатолий Иванович

К.ю.н., дочент, Владимирский юридический институт ФСИН России gudkovaniv@yandex.ru

Красильщиков Анатолий Владимирович К.ю.н., дочент, Владимирский юридический институт ФСИН России krasilschikov@inbox.ru

Мищенко Вячеслав Иванович

К.ф.н., дочент, Владимирский юридический uнституm ФСИН Poccuu vyacheslav-mischenko@mail.ru

Аннотация. В статье исследованы некоторые проблемы правоприменения в сфере жилищного законодательства. В частности, освещены трудности, связанные с возможностью приобретения освободившихся жилых помещений в коммунальных квартирах другими их сособственниками. Раскрываются правовые коллизии действующего жилищного законодательства и его противоречивое понимание в разных субъектах Российской Федерации, а также в различных судебных инстанциях. Предлагаются варианты разрешения данной проблемы, как путем толкования коллизионных норм В соответствии с общим смыслом и принципами жилищного законодательства, так и внесения соответствующих в него изменений. Авторы считают, что предложенные ими решения будут служить в интересах и частных субъектов, и публично-правовых образований.

Ключевые слова: жилищное право, коммунальная квартира, освободившееся жилое помещение, преимущественное право покупки, муниципальная собственность, коррупция, толкование.

Однако, как показывает практика применения жилищного законодательства, за последние 15 лет вопросов осталось не меньше, а те явления, которые должны были искоренены как архаизмы, продолжают иметь место, создавая проблемы гражданам страны и почву для коррупционных проявлений недобросовестных государственных и муниципальных служащих.

Как мы уже отмечали выше, создание достойных жилищных условий, ликвидация коммунального жилья должна была стать одной из основных целей нового жилищного законодательства. К сожалению, прямой нормы, запрещающей коммунальные квартиры в жилищном кодексе, не появилось. Несмотря на это, в законодательстве явно просматривается общая направленность норм на уход от данных форм удовлетворения жилищной потребности граждан. 
Россия участвует в Международном пакте об экономических, социальных и культурных правах [1]. Статья 11 этого пакта «Право на достаточный жизненный уровень» включает в себя право на жилище. Замечание общего порядка № 4 «Право на достаточное жилище» (пункт 1 статьи 11 Пакта) даёт определение такого жилища (пункт 7):

«Надлежащее жильё означает отдельное жильё, надлежащую площадь проживания, надлежащую безопасность, надлежащее освещение и вентиляцию, надлежащую основную инфраструктуру и надлежащее местоположение с точки зрения работы и основных услуг, причём всё это - по разумной цене».

Отечественный законодатель в ст. 59 ЖК РФ также акцентирует внимание на данной проблеме: освободившееся жилое помещение в коммунальной квартире... предоставляется по договору социального найма проживаюшим в этой квартире нанимателям и (или) собственникам...!

На решение этой проблемы обращают внимание и высшие судебные инстанции России. Так, пункт 31 Постановления Пленума Верховного Суда РФ от 2 июля 2009 г. N14 [5] гласит о том, что «судам необходимо иметь в виду, что Жилищный кодекс Российской Федерации не содержит норм о праве члена семьи нанимателя жилого помещения потребовать от наймодателя изменения договора социального найма путем заключения с ним отдельного договора социального найма. В связи с этим требование члена семьи нанимателя о заключении с ним отдельного договора найма жилого помещения удовлетворению не подлежит».

Поскольку жилищное право находится в совместном ведении Российской Федерации и субъектов РФ, прослеживается позитивная законодательная работа в этом направлении законодательных органов власти ряда регионов РФ.

Так, пункт 7 Закона Санкт-Петербурга «О порядке и условиях продажи жилых помещений государственного жилищного фонда Санкт-Петербурга» от 02.05.2006 N169-27 [4] гласит: «гражданам, являющимся нанимателями и(или) собственниками (членами семьи нанимателей и(или) собственников) жилых помещений (комнат) в коммунальных квартирах, свободные жилые помещения (комнаты) в данных коммунальных квартирах продаются на основании их заявления в случаях, если в результате продажи данные коммунальные квартиры становятся отдельными».

На наш взгляд, в данных нормах прослеживаются два момента. Во-первых, не допускается создание новых коммунальных квартир. Во-вторых, коммунальные квар- тиры, которые уже существуют, должны постепенно прекратить свое существование и стать отдельными.

К сожалению, далеко не все регионы приняли законы, касающиеся порядка и условиях продажи жилых помещений государственного и муниципального жилищного фонда, что породило массу трудностей для жильцов коммунальных квартир в вопросе приобретения освободившегося жилья. Возможно трудностей и нет, когда одни лица выехали из коммунальной квартиры, а другие сразу после этого заявили право на освободившееся помещение в течение небольшого промежутка времени.

Но всё становится гораздо сложнее, когда одни жильцы коммунальной квартиры расселены уже давно и занимаемые ими ранее помещения де-юре принадлежат муниципальному образованию, а оставшаяся часть квартиры от других граждан (в свое время их приватизировавшим) перешла по договору дарения новым лицам (ранее никогда не проживавшим в этой квартире) [6].

И вот когда новые счастливые обладатели коммунальной комнаты хотят расширить, улучшить свои жилищные условия путем законного приобретения на основании п. 3 ст. 59 ЖК РФ (покупки у муниципального образования) не занятого жилого помещения, то оказывается, что это сделать практически невозможно.

Как оказалось, главной проблемой в реализации своего права, закрепленного в ст. 59 ЖК РФ для этих собственников, стала неудачная конструкция содержащейся в ней нормы, позволяющей различным субъектам правоприменения толковать термин «освободившееся жилое помещение» по-разному.

Полагаем, что законодатель в ч. 3 ст. 59 ЖК обозначая жилье освободившимся, в первую очередь, акцентировал внимание на преимущеетвенное право у граждан (проживающих или имеющих в собственности комнаты в коммунальной квартире), на возможность распоряжаться освободившимися комнатами в той или иной форме, исключая вероятность заселения в освободившиеся помещения других граждан.

То есть, если это малоимущие и нуждающиеся, проживающие в этой квартире, то они имеют преимуще ство перед другими гражданами на получение освободившихся комнат по договору социального найма, минуя очередность получения жилья и исключая всех возможных кандидатов на эти освободившиеся комнаты в соответствии с ч. 1 ст. 59 ЖК РФ. Статус освободившегося жилого помещения (в данном случае - комнаты в коммунальной квартире) трактуется, что нет граждан, за которыми закреплено хоть какое - то право распоряжаться этими помещениями. 
Если нет граждан, которые указаны в ч. 1 ст. 59 ЖК РФ, то преимущество социального найма предоставляется проживающим в этой квартире нанимателям и (или) собственникам, которые могут быть признаны малоимущими (даже не обязательно иметь этот статус, достаточно подтвердить, что признаки малоимущих присутствуют) и обеспечены менее нормы предоставления (ч. 2 ст. 59 ЖК). Статус освободившегося помещения

в данном случае трактуется таким образом, что нет граждан, за которыми закреплено хоть какое-то право распоряжаться этими помещениями.

Обратим особое внимание на исследуемый нами случай ч. 3 ст. 59 ЖК РФ, когда в помещении:

а) отсутствуют граждане, за которыми закреплено хоть какое - то право на эти помещения или право распоряжаться этими помещениями, т.е. помещение свободно от каких - либо обязательств и прав перед другими гражданами или претендентами на это помещение, (когда оно является освободивиимся от обязательств и прав на помещения в коммунальной квартире);

б) отсутствуют граждане из ч. 1 ст. 59 ЖК РФ;

в) отсутствуют граждане из ч. 2 ст. 59 ЖК РФ. Но, присутствуют граждане, наниматели или собственники комнаты, которые проживают в этой коммунальной квартире и обеспечены общей площадью жилого помещения на одного члена семьи менее нормы предоставления [6].

Согласно норме права ч. 3 ст. 59 ЖК РФ, учитывая, что нет других претендентов на право занять эти комнаты, законодатель предоставляет возможность выкупить по договору купли - продажи освободившиеся от обязательств и прав комнаты в коммунальной квартире гражданам, которые уже там проживают и обживаются обычной мирской жизнью.

Особо отметим, что в случае осуществления данной сделки конструктивно решаются сразу несколько социальных задач, чему и призвано служить жилищное законодательство:

а) граждане, которые выкупают по договору купли продажи освободившееся помещение (комнату) переходят из категории обеспеченных менее нормы предоставления на одного члена семьи в категорию счастливых собственников отдельной квартиры (причем вся семья), уменьшая тем самым количество нуждающихся в нашей стране за счет самих нуждающихся;

б) нет необходимости искать для нуждающихся в этой коммунальной квартире другое подходящее им жилье и создавать дискомфорт переездов и адаптаций к новому месту жительства; в) ликвидируется коммунальная квартира, создается отдельное полноценное жилье;

г) пополняется муниципальный бюджет за счет продажи этих помещений;

д) бремя содержания квартиры целиком переходит на частного собственника, освобождая муниципалитет от необоснованных издержек.

Однако муниципальные власти зачастую отказывают в предоставлении по договору купли-продажи жилых таких помещений, мотивируя это тем, что «...указанные жилые помещения в коммунальной квартире освободились до того, как заявитель стал собственником комнаты и зарегистрировался в нем по месту жительства, то есть указанные жилые помещения в коммунальной квартире не являются для заявителя освободившимися» [6]. Заявитель обращается в суд, что выливается в ряд разбирательств, которые показывают неоднозначность толкования категории «освободившееся жилое помещение» судами различных инстанций.

Решения суда общей инстанции и кассационной инстанции оказываются в пользу органа публичной власти [6]. Акцент трактовки в них делается не на освободившееся от обязательств и прав, а на строку из первой части ст. 59 ЖК РФ, которая гласит «...предоставляется по договору социального найма проживающим в этой квартире нанимателям и (или) собственникам, если они на момент освобождения жилого помещения признаны или могут быть в установленном порядке признаны малоимущими и нуждающимися в жилых помещениях. Мы полагаем, что в данной трактовке теряется смысл ч. 3 ст. 59 ЖК РФ предоставить свободное от обязательств и прав помещение в коммунальной квартире по договору купли-продажи гражданам, которые приобрели комнату на праве собственности в этой коммунальной квартире, но помещения на этот момент уже были свободными от обязательств и прав. Поэтому заключить договор купли продажи невозможно (даже если на момент подачи заявления в комиссию нет претендентов на освободившиеся комнаты, то все равно отказывают по причине «не были свободны на момент приобретения». В этом случае граждане обязаны доказать, что они вселились до момента освобождения, а не после.

Если в целом вникнуть в смысл определения суда кассационной инстанции, то дефиниция о том, что «комнаты не могут считаться освободившимися в случае, если на момент вселения в квартиру были свободны», выглядит как-то не совсем логично. В итоге получается пробел в законодательстве: на помещение никто не претендует, оно является освободившимся от прав и обязанностей, но продать его невозможно, так как граждане пропустили момент освобождения жилого помещения и шансов 
приобрести его на основании ч. 3 ст. 59 ЖК РФ нет, так как момент освобождения уже не вернуть.

На наш взгляд, самым оптимальным решением в данной ситуации было бы изменение ч. 1 ст. 59 ЖК РФ путем удаления из нее фразы «на момент освобождения жилого помещения», т.к. в начале статьи 59 ЖК РФ помещение и так обозначается «освободившимся».

Однако мы знаем, что изменения в законодательстве представляют собой процесс не быстрый, а проблемы у граждан возникают прямо сейчас, поэтому считаем возможным для разрешения обозначенных проблем применять уже существующие нормы.

Полагаем, что с учетом неоднозначных решений нижестоящих судов, помимо буквального лексического толкования нормы ст. 59 ЖК РФ, нелишним было бы применить к разрешению данного дела аналогию права и аналогию закона (ст. 6 ГК РФ). Общий смысл граждан- ского и жилищного законодательства, с учетом требований добросовестности, разумности и справедливости подсказывает нам, что решение апелляционной инстанции по данному случаю было бы верным [6], и вело к реализациям задач, обозначенных нами выше.

Что касается аналогии закона, то полагаем возможным применить к данной ситуации пункт 7 Закона Санкт-Петербурга «О порядке и условиях продажи жилых помещений государственного жилищного фонда Санкт-Петербурга» от 02.05.2006 N169-27, позволяющий приобретать помещения (комнаты) в коммунальных квартирах в случаях, если в результате продажи данные коммунальные квартиры становятся отдельными.

В свою очередь, не урегулирование данного пробела и возможность двоякого толкования нормы ст. 59 ЖК РФ создает предпосылки для коррупционных проявлений в области перераспределения и реализации государственного и муниципального жилья.

\section{ЛИТЕРАТУРА}

1. Международный пакт об экономических, социальных и культурных правах [Электронный ресурс]: Принят 16.12.1966 Резолюцией 2200 (XXI) на 1496-м пленарном заседании Генеральной Ассамблеи 0ОН// Доступ из справ.-правовой системы «КонсультантПлюс» (дата обращения: 15.05.2020).

2. Гражданский кодекс Российской Федерации. Часть первая: [Федер. закон от 30 нояб. 1994 г. № 51-Ф3: принят Гос. Думой 21 окт. 1994 г.] // Собр. законодательства Рос. Федерации. — 1994. — № 32, ст. 3301.

3. Ж Жилищный кодекс Российской Федерации: [Федеральный закон от 29 декабря 2004 г. № 188-Ф3: принят Гос. Думой 22 дек. 2004 г.] // Собр. законодательства Рос. Федерации. - 2005. - № 1, ст. 14.

4. 0 порядке и условиях продажи жилых помещений государственного жилищного фонда Санкт-Петербурга: Закон Санкт-Петербурга от 02.05 .2006 N169-27 (ред. от 09.04.2020) (принят ЗС СПб 05.04.2006)// Доступ из справ.-правовой системы «КонсультантПлюс» (дата обращения: 15.05.2020).

5. О некоторых вопросах, возникших в судебной практике при применении Жилищного кодекса Российской Федерации: Постановление Пленума Верховного Суда РФ от 2 июля 2009 г. № 14 //Бюллетень Верховного Суда Российской Федерации. — 2009.— № 9.

6. Определение Второго кассационного суда общей юрисдикции от 19.12.2019 N88-1887/2019 по делу N2-254/2019// Доступ из справ.-правовой системы «КонсультантПлюс» (дата обращения: 15.05.2020).

( Гудков Анатолий Иванович ( gudkovaniv@yandex.ru ),

Красильщиков Анатолий Владимирович ( krasilschikov@inbox.ru ), Мищенко Вячеслав Иванович ( vyacheslav-mischenko@mail.ru ). Журнал «Современная наука: актуальные проблемы теории и практики» 